\title{
FROM MISPRISION TO TRAVESTY \\ Harold Bloom's Use of Rabbinic Sources
}

\author{
Inge Birgitte Siegumfeldt
}

\begin{abstract}
$\propto$
A в S T R AC T Jewish thought is assigned a privileged place in Harold Bloom's agonistic theory of literary production and allegedly provides a model for the concepts for which he is best known: the anxiety of influence and creative misprision. Nevertheless, Bloom's view of rabbinic exegesis as 'rebellious' and 'heretical' emerges as a travesty. His attempt to ascribe a radical, competitive individualism to what is essentially a body of collective authorship reflects a serious misconception of the nature of rabbinic thought and a scant, ill-informed reading of the sources.

What I propose to do here is both descriptive and evaluative: to examine and characterize the ways in which Bloom handles rabbinic sources, and then to step outside the Bloomian circle in order to put his (mis)readings to the tests of standard scholarly inquiry. As we shall see, again and again, the test is failed. It may be that one reason for this is technical, that is, Bloom's lack of the requisite linguistic and historical knowledge. But beyond the detailed catalogue of elementary scholarly error-a substantial affair, as we shall see-there is another story to be told. It is a story of appropriation and distortion motivated by the impact of one theory (Bloom's) on another (the rabbinic) with which in reality it has very little in common.
\end{abstract}

or anyone reviewing the history of theory and criticism over
the past fifty years, the 7os and 8os stand out as a peculiarly
turbulent and creative period. This was the time when literary 
criticism, pressured by the 'theoretical' (what then came to be institutionalized as Literary Theory), turned outwards, moving into the spaces occupied by other disciplines: linguistics, philsopophy, the social sciences, psychoanalysis. As these cross-disciplinary transactions settled into new orthodoxies of their own, they eventually themselves became objects of analytical and historical inquiry-'literary theory' now has almost as many histories as it has theories.

In this essay, I wish to pause momentarily over one of these more or less exoteric encounters: the prima facie odd dialogue between literary criticism and Jewish Studies, and more specifically to review the interventions of a figure closely associated with this encounter, the distinguished American literary critic, Harold Bloom.

Bloom, has frequently advertized his reliance on Jewish thought as the primary source of inspiration for his agonistic theory of literary production. He lays explicit claim to aspects of the rabbinic tradition for his own work, especially in his elaboration of the concepts for which he is best known: 'the anxiety of influence' and 'creative misprision'. The proposition he brings to these ideas is that Jewish writers engage in a sustained creative mis-reading of their precursors such that they can be seen to provide a model for how poetry and its histories are to be understood. More specifically, Bloom projects the example of medieval kabbalistic speculation onto his view of poetry as a battleground fought out between rivals seeking primacy and autonomy: »the Lurianic story of creation», he says, »now seems to me the best paradigm available for a study of the way poets war against one another in the strife of Eternity that is poetic influence» ${ }^{1}$.

Needless to say, there is much marvel at this eye-catching projection of Judaic thought onto poetic theory, but most notably-to come straight to my principal point - the fact that this declaration entails a highly distorted image of kabbalistic intellectual culture. Cataloguing some of the detail of this misrepresentation is one of the aims of this paper, with particular reference to the triad of theoretical works written in the early 1970 s The Anxiety of Influence, A Map of Misreading and Kabbalah and Criticism. But at once beyond the detail and underlying it, there is a more general problem to do with the logical structure of Bloom's theoretical circle.

In so far as the Bloomian model of intra-poetic strife turns on the 
notion of 'mis-reading', the 'strong' misprision of the precursor-poet as the foundation of a dynamic, innovation-centred tradition, it necessarily prompts a question regarding the status of the theory itself, that is, a question as to its self-referentiality. Acts of (mis)reading, translated into acts of writing, are not uniquely the province of the poet, but also that of the critic. Does this then mean that literary criticism is subject to the same processes as poetry itself, such that, if, in terms of Bloom's theory, Wordsworth creatively misreads Milton in order to carve out a ground of poetic originality, this in turn licences Bloom to produce a creative misreading of Wordsworth in order to clear a space for originality on the terrain of criticism? The drift of the question is thus clear: does Bloomian theory apply only to first-order literary representations or does it also implicate second-order critical representations? And if it does implicate the latter, what constraints does this place on the legitimacy of the critic's readings not only of poets but also of other critics, theories and scholarly traditions? Is Bloom, from the terms of his own theory, free to 'mis-read' according to his needs as a critic, or is he constrained by standards external to the notion of creative misreading, such as accuracy, fidelity to sources and truth?

These questions regarding Bloomian agonistics are especially relevant to its alleged 'Jewish' dimension. Bloom categorically asserts that the kabbalistic model is not just one in a heterogeneous range of references. It is explicitly advertised as foundational and constitutive. There is, it would appear, something special about the rabbinic tradition, a way in which it uniquely speaks to and nourishes the form of inquiry onto writing and reading which Bloom is anxious to promote through his own work as a critic. This is why the questions concerning the logical structure of his theory are particularly pertinent here, and are so in two interconnected respects. First, does the privileged place assigned to Rabbninics mean that it is, and has to be, a privileged object of Bloomian misreading? In connection with Bloom's recourse to kabbalah, this seems to be the case: as we shall see shortly, he openly confesses to a misreading of kabbalah. Secondly, and more awkwardly, if the preferential treatment of rabbinics entails the claim that this tradition itself warrants misreading, including misprision of itself, such that it can serve as a model for the Bloomian enterprise, then we must ask what limits are set for misreading? How do we distinguish between 
creative interpretation and travesty? Whatever it is that the theory of misreading might involve, in its application to scholarly understanding of past traditions it surely must be distinguished from misrepresentation. I take it that Bloom would not dispute this distinction as such, since to do so would implicitly ruin the whole project of saying something held to be true of our practices of reading and writing. On the other hand, it is unclear from the theory itself just how far that commitment-to accuracy and truth-can be coherently built into the theory itself without placing impossible strains on it.

Here, then, we immediately encounter a series of paradoxes. Bloom treats Judaic sources in the same way that, in the terms of his agonistic theory, he alleges poets treat theirs, that is, by a strategy of creative misreading. However, there is a predictable sting in the tail: Bloomian misprision of rabbinic texts often results in distortion. It would of course be notionally consistent with the theory that getting it wrong is the royal road to getting something right, that is, misprision as a strategic force field for the generation and deployment of creative 'strength', but here the intellectual net tightens to the point of strangulation. Playing a creative game with sources for one's private intellectual purposes is one thing ${ }^{2}$, claiming 'authorization' from the sources for the rules of the game is quite another. That is tantamount to saying that the Jewish texts themselves demand that we actively mis-read them in order to do the sort of thing (acts of interpretation, for instance) they recommend. But there is no evidence that they issue any such demand. Bloom may have responded only too eagerly to the invitation explicit in the Judaic tradition to 'turn the Torah and turn it again', but he then fails to heed the principle of fidelity to sources it presupposes. The internally self-confirming structure of Bloom's thought therefore remains vulnerable to the imposition of a simple test: the test of elementary scholarly standards. As I shall show, Bloom fails to comply with these standards time and again, often for the most straightfoward reasons of all, namely lack of the requisite forms of linguistic, historical and conceptual knowledge.

For Bloom, literature is a battle between 'strong' equals, that is, innovative poets separated in time but united in their struggle for space. This agonistic drama stages the belated revisionist engaged in a soliloquy which takes the form of imaginary dialogues with his 
predecessors. The overriding theme here is 'Bildung', the formative factor being oppressive anxieties of parental influence, and the outcome a radical individualism: a story of generational conflict, patricide and the fantasy of self-begetting. More specifically, the young poet desperately seeks to overcome the influence of canonized precursors in order to emerge within the tradition that fostered him as a subject fully equipped with voice, will and power to influence future latecomers in turn. This »anxiety of influence», Bloom asserts, »stems from the ephebe's assertion of an eternal, divinating consciousness that nevertheless took its historical point of departure in an intra-textual encounter, and most crucially in the interpretative moment or act of misprision contained in that encounter $»^{3}$. The precursor, the »voice of the other, of the daimon,» can be suppressed but never silenced, as Bloom argues in a terminology that is singular if not esoteric in its allusion both to early Christian heresy and to modernist Eliot. It »is always speaking in one; the voice that cannot die because already it has survived death - the dead poet lives in one» ${ }^{4}$. Thus primacy and autonomy cannot be fully achieved, but the oppressive force of the Oedipal trauma is relieved by fantasies of patricide and self-begetting, the immediate anxieties of influence remedied by misprision. "Strong poets must be mis-read;» Bloom maintains, "there are no generous errors to be made in apprehending them, any more than their own errors of reading are ever generous. Every strong poet caricatures tradition and every strong poet is then necessarily mis-read by the tradition he fosters $»^{5}$. Bloom thus perceives canon formation as a dialectical process: the simultaneous breach of and restoration to a given literary tradition. The belated poet 'swerves' from its conventions and thereby forms a stance of his own and, if sufficiently accomplished, takes up his own place in the ranks of celebrated literary figures. Both departure and prodigal homecoming turn on misprision.

Here I have merely repeated what anyone even vaguely familiar with Bloom's writings already know. What happens however when we take this characterization deep into the field of sources Bloom constructs to validate his account of poetry? 


\section{[I]}

These sources are both numerous and various, straddling a territory that includes the examples set by the Romantic poets; Freudian psychoanalysis (the Oedipal story); philosophy (especially ideas and terms from the Nietzcho-Heideggerian tradition); anthropology; theology. The sheer diversity of these borrowings tells us much about the nature of Bloomian 'method': it is fundamentally opportunistic and eclectic, picking up an idea here, copying another there, with a view to blending them into a model of influence and misprision. Jewish thought is assigned a privileged place in this syncretic web of inspiration. In general terms, it is the rabbinic insistence on interpretation paired with the exegetical principles of heterogeneity and intertextuality which provides a foundational element in Bloomian poetics. And more specifically, the cosmogonic and theogonic speculation of medieval kabbalah are employed as models for the concepts of misreading and influence.

\section{Second Order Sources}

Bloom's knowledge of kabbalah derives from Gershom Scholem's massive and meticulous exposition of its thought and history. As we shall see, it is Scholem's work - with its own interpretations - that provides the basis for Bloom's 'misreadings' of central Judaic principles, and so we must go by way of this second order source in order to examine his alleged employment of first order material.

In 1959 Bloom held a Visiting Professorship at the Hebrew University in Jerusalem where Scholem was established as the foremost authority on kabbalah. Here Bloom became intimately familiar with his work, to the point in fact where "most of what follows in this essay [Kabbalah and Criticism] is based upon either this book $\left[^{6}\right]$ or on Scholem's other major studies of Kabbalah». He cannot depart from Scholem, he acknowledges, »on any factual matters in Kabbalistic scholarship» but will only make some suggestions as to the »continued relevance of Kabbalah for contemporary modes of interpretation, and a few personal speculations on how Kabbalah itself might be interpreted from some contemporary perspectives» ${ }^{7}$.

As I shall demonstrate below, Bloom's 'speculations' are indeed 'personal', to the point, in fact, of frequently verging on inexactitude. 
They also involve the foregrounding of themselves as original, thus attempting to usurp Scholem's precedence. For instance, while drawing attention to certain literary concerns and practices which rabbinic commentators and poets indeed share, Bloom seems to imply that this affinity has been discovered by none other than himself: »I myself find it curious that no one, in the entire history of scholarship, ever has speculated on the literary motives of the Kabbalists» ${ }^{8}$. Naturally, we may wonder what he intends 'the entire history of scholarship' to encompass, and what exactly is meant by 'literary motives'? Is he thinking of 'scholarship' as pertaining exclusively to Western academia, and of 'literary' as that which takes certain conventional generic forms? Nevertheless, having studied Scholem, surely he was familiar with both the inventive and profoundly scholarly nature of kabbalistic commentary, as well as with the substantial evidence, Scholem presents - precisely in Kabbalah, the work Bloom himself highlights - to the effect that it has been perceived as such since the Renaissance by Christian and Jewish thinkers alike 9 . And surely he cannot have missed either Scholem's emphasis on the sophisticated integration of the 'literary' with the intellectual 'motives' of speculative kabbalah or the attention he specifically gives to the common ground shared by kabbalists and poets:

And poets have one link with the masters of the Kabbala, even when they reject Kabbalistic theological formulation as being still too emphatic. This link is their belief in language as an absolute, which is as if constantly flung open by dialectics ${ }^{10}$.

Such breaches of the principle of honouring one's sources are not uncharacteristic of Bloom's practice: he seems to feel at liberty to appropriate and propose as his own ideas put forward by predessors.

His claim, moreover, that in »urging a Kabbalistic model» his motives »are pure enough, and it may be worth remarking that I did not set out upon this enterprise with a Kabbalistic model consciously in view. But it was there nevertheless.... ${ }^{11}$ cannot be but disingenuous. The 'Kabbalistic model' with its applicability to current notions of reading and writing was by no means just 'there', as an epiphany appearing out of the blue-it derives from his acquaintance with Scholem's work dating back to the late 1950 . 


\section{First Order Sources}

If we then look at the first order kabbalistic sources on which Bloom appears to rely, we find further appropriations mixed with a series of divergences that at times directly contradict principles and values vested in that tradition.

Jewish theosophy was revived in medieval Europe and crystallized into the mode of exegetical thought and practice generally referred to as kabbalah. After the expulsion from Spain and Portugal in 1492, kabbalists began increasingly to contemplate the condition of exile recorded in Scripture and reflected in life and language. »Life was conceived,» Scholem argues, »as Existence in Exile and in self-contradiction, and the sufferings of Exile were linked up with the central Kabbalistic doctrines about God and man ${ }^{12}$. This focus was to become prominent half a century later in the Safed School where the rabbis Moshe Cordovero (1522-1570) and Isaac Luria (1534-1572) devised their theogonic and cosmogonic theories of emanation. Here Divine manifestation is represented by the ten s'firot. These configurations or names of God are perceived as mutually interconnected in an intricate structure where each s'firah not only contains the entire pattern of ten attributes, it is also connected to the other nine by an infinite number of differentiating aspects, the b'hinot. Cordovero mapped these relations between s'firot by distinguishing six central b'hinot that characterize the dialectical relations between emerging configurations of God.

Luria divided the primordial process of Creation into three stages: tsimtsum, shvirat-ha-keilim, and tikkun. In the initial phase, tsimtsum, a 'contraction' takes place within the Infinite to clear a finite space in which creation can take place, thus separating subject and object within the original source. A void thereby established, God inscribed His Name ${ }^{13}$ on the ether, and from the initial letter, the Yud, the entire Hebrew alphabet emerged ${ }^{14}$. The second phase in the Lurianic pattern, shvirat ha-keilim, is 'the breaking of the vessels': the light radiated from the twenty-two Hebrew letters formed the shape of the first Creation, Adam Kadmon. Too powerful, however, to be contained in the vessel, it burst, and so shattered into pieces. The final phase, tikkun, represents a 'restoration' by which rays of fragmented light came together and formed a new but flawed vessel. Creation, as we know it from Genesis, then followed, though inherently marked by a preliminary rupture. 
According to Luria, this pattern of self-reduction followed by rupture and restoration constitutes the principle of any creative process: the name of the maker signed on the void of self-contraction, in turn exploded and reproduced in a deficient form, thus accounting for the exilic condition that prevails in the mundane world.

It is these two theories of cosmogonic and theogonic emanation, Luria's tripartite creational pattern paired with Cordovero's definition of differentiating aspects in the Godhead, which allegedly provide the constitutive elements in Bloom's 'Map of Misprision'. His transformation of the s'firotic configurations into texts, "divine poems, each a text in itself ${ }^{15}$, interacting through the b'hinot is straightforward and essentially concords with kabbalistic thought. So does the notion that each 'text' is subjected to the tripartite creational pattern when emerging from the structure of interconnected relations.

Applying the Lurianic dialectics to my own litany of evasions, one could say that a breaking-of-the-vessels always intervenes between every primary (limiting) and every antithetical (representing) movement that a latecomer's poem makes in relation to a precursor's text ${ }^{16}$.

The initial swerve by which Bloom's belated poet embarks upon his agonistic journey towards 'self-manifestation' engenders a limitation, he argues, "a contraction or withdrawal,» that 'breaks' the first 'false' creation. The "answering movement» then takes place by a restoration, a re-writing which is perceived as a »completion that is also an opposition ${ }^{17}$. At this point, the initial deviation from the canon fails, and the ephebe returns, although altered by his swerve, to the source. This process is enacted thrice in Bloom's map, each time strengthening the innovator on his way to 'poetic self-hood' through contraction and rupture. Thus, perpetually alternating between presence and absence, early and late, sameness and difference, continuity and discontinuity, he finally emerges in his own right, according to Bloom, through dialectical interplays between theses, antitheses, and syntheses.

By these 'personal speculations' as to the 'continued relevance of Kabbalah for contemporary modes of interpretation', Bloom actually achieves a successful transplantation of the Lurianic model onto the mechanisms of literary production and canon formation when perceived as a process alternating between tradition and innovation. His 
reading of Luria's cosmogony is indeed creative and its transposition into the 'Map of Misprision' demands but few alterations.

This however is not the case when it comes to his employment of Cordovero's b'hinot. The transformation of these differentiating aspects into Bloom's own revisionary ratios requires no less than a metamorphosis involving, absurdly, a conversion from the Hebraic to the Greek conceptual worlds. Not only are the b'hinot re-named by terms taken almost exclusively from ancient Hellenic sources, the process of emanation they illustrate are also modelled on the Oedipal myth ${ }^{18}$. This is indeed a most striking cross-cultural move: the theogonic speculation of rabbinic sages transformed into a patricidal drama among Greek kings.

On closer inspection, moreover, it soon becomes clear that Bloom has little if any first hand knowledge of Cordovero's Pardes Rimmon$\mathrm{im}^{19}$. Although he frequently invokes this source in Kabbalah and Criticism, we find that his elaborate presentation of the b'hinotic system differs significantly from Cordovero's original, stylistically, conceptually and in terms of the sequence by which the b'hinot are ordered. Then if we compare this exposition with Scholem's, we find not only an almost verbatim reproduction of phrases, but also repetition of certain omissions Scholem chose to make in relation to Cordovero's text. In an earlier study ${ }^{20}$, I have discussed Bloom's paraphrase of Scholem in detail, thus a single example will suffice for purposes of illustration: "According to Cordovero» as he repeatedly puts it, and thereby claiming the authority of the original, Bloom concludes his presentation of the b'hinot in this manner: "...the following Sefirah, next in sequence, is emanated to its proper place, after which the whole cycle begins again with the first behinah of the following Sefirah» ${ }^{21}$. In terms of terminology and word order these phrases almost exactly match Scholem's: »(6) the aspect by which the following Sefirah is emanated to its own place, at which point the cycle begins again» ${ }^{22}$. Cordovero's original manuscript, however, is quite different in style and brevity: the »sixth is apparent in its proper place of existence». Moreover, Cordovero explicitly matches the b'hinot in pairs of three, the »three last b'hinot of the Keter are the three first of the Keter ${ }^{23}$. In order to emphasize the perpetual repetition of these alternating movements in the process of emanation, Scholem chooses here (but discusses the 
original wording in much detail elsewhere) to rephrase the original text and describes the structure as a 'cycle that begins again'. Bloom repeats this elucidation verbatim, then proceeds with what may have been intended as a simplification of Scholem, but which nonetheless reflects a severe misunderstanding of Cordovero, for the cycle does not begin again "with the first behinah of the following Sefirah», as Bloom purports: the b'hinot do not follow one upon the other in consecutive order, they alternate between the upper and lower three ${ }^{24}$. Had Bloom studied Pardes Rimmonim, as he claims time and time again, he could not have missed this crucial point in Cordovero's theory.

Nevertheless, in Kabbalah and Criticism Cordovero is frequently foregrounded not merely as a primary source of inspiration for Bloom but also as a most resourceful innovator providing important insights deemed to be relevant even for modern categories of secular thought. In Bloom's estimation he not only »uncovered the normative structure of images, of tropes and psychic defenses, in many central revisionary texts, including many poems of the last centuries», he must also be considered »the first Structuralist, an unacknowledged ancestor of many contemporary French theorists of the 'human sciences' ${ }^{25}$. However, if Cordovero's ideas are "crucially instructive» ${ }^{26}$ for contemporary theory, Bloom's 'translation' of them into 'terms that can be understood today ${ }^{27}$ would seem contradictory. If we then turn to A Map of Misreading, Cordovero, Bloom's great $»$ dialectician of influence ${ }^{28}$ is not acknowledged as a source. Astonishingly, the six-fold revisionary aspect is here referred to as Bloom's $» \mathrm{own}^{29}{ }^{2}$, attributed, we learn, to inspiration deriving jointly from Luria's creational pattern and the »Wordsworthian crisis-poem, which,» he declares, »is the paradigm for the modern lyric.» ${ }^{30}$ So, where the details of Scholem's work are elided and Cordovero's invoked as sources of inspiration in Kabbalah and Criticism, in the previous ${ }^{31}$ volume of Bloom's theoretical triad the latter is (conveniently) suppressed partly in order, we might well suspect, to endow Bloom's own erroneous 'reading' of primary material exclusively through a secondary source with the authority of primacy.

\section{Language}

If we then apply the standard scholarly test to Bloom's Hebrew terminology we find a series of errors across the fields of etymology, 
grammar and transliteration, which reveal a serious deficiency in elementary linguistic knowledge. The most conspicuous errors here derive from a lack of consistency between grammatical forms. Nouns are represented by infinitives, as in the sentence that would immediately grate on the ear of anyone even remotely familiar with Hebrew: "...the new poem or poetry is a total interpretation or lidrosh ${ }^{32}$ of the poem...» ${ }^{33}$. (In English he would be saying: 'poetry is a to enquire of the poem').

But there are others. In a single sentence intended to define the Lurianic term 'tsimtsum', Bloom manages to make no less than three elementary mistakes: "Zimzum, as I've said already, derives from the verb mezamzem, to 'draw in the breath'» ${ }^{34}$. First, there is another instance non-congruent grammatical forms, for rather than following the conventional system of citing Hebrew words in their root form, he gives us the verb in the present tense, metsamtsem, and then translates it by the infinitive 'to draw in the breath'. Secondly, there is a failure to attend to the literal meaning of Hebrew terms: although 'tsimtsum' has come to signify the metaphor of God 'holding His breath' in certain versions $s^{35}$ of Lurianic cosmogony, its root meaning is not that-it is »reduction» or »contraction». Finally his English transliteration is inconsistent with Hebrew phonetics: unlike Scholem, Bloom here employs the German transliteration of the letter tsadik in the word 'zimzum' thus representing the unvoiced ' $t s$ ' by the voiced ' $z$ '.

Bloom also seems entirely unaware of what it is he transliterates in his Roman spelling of the Hebrew word for nothingness, which occurs frequently particularly throughout Kabbalah and Criticism. Bloom writes: »As Ein-Sof has no attributes, his manifestation is necessarily as ayin ('nothing')» ${ }^{36}$. Bloom forgets the fact that the Ein of the first term I have italicized above is identical to the second, and should therefore have the same spelling ${ }^{37}$. In a system of transliteration where the word for nothingness is spelt 'ein', 'ayin' will logically represent either the

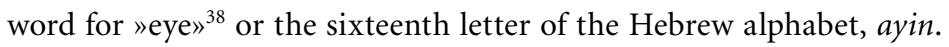
This inconsistency presumably derives from the use of two different systems of transliteration, most likely a German and an English one, but it still reveals a distinct ignorance of root meaning.

It is true that there is a margin for variance in Hebrew etymology, but even when Bloom does know his source, his attention to accuracy 
is less than adequate. The term 'kabbalah' for instance is variously defined: correctly, as in »the word 'kabbalah' means 'tradition,' in the particular sense of 'reception'», but then inaccurately, as in »Kabbalah, which means 'the given'» ${ }^{39}$, thus stressing the imparting of knowledge rather than a received influx.

These errors, selected from a long list of examples, suggest a less than comprehensive knowledge of the Hebrew language and, perhaps more importantly, they testify to Bloom's careless handling of sources: an inadequate scholarly practice, which stands out in stark contrast to the rabbinic principle of meticulous attention to accuracy and detail.

\section{[2]}

However, beyond the catalogue of elementary scholarly error-a substantial affair, as we have seen-there is another story to be told. It is a story of appropriation and distortion motivated by the impact of one theory (Bloom's) on another (the rabbinic) with which in reality it has very little in common. In other words, it is not only the formal treatment of sources that reflects Bloom's »dubious scholarship» ${ }^{40}$, it is also the ways in which conceptual frameworks are presented and employed.

Structured according to Bloom's misapprehension of the b'hinotic system, then correllated with Luria's thrice repeated pattern of rupture and restoration, Cordovero's-now Bloom's - six movements constitute the 'Map of Misprision'. Here they trace the linear progression of "the strong poet's life-cycle» ${ }^{41}$ by way of antagonistic images, Oedipal defenses, tropes of rivalry compounding an "assertion against influence as being a ritualized quest for identity» ${ }^{42}$ that turns on the suppression of precursorial voice into echoes resounding merely as a familiar otherness.

Bloom proposes this grand scheme of (poetic) self-invention as no less than a 'Primal Scene' intended to map out a stage between origins and creation. The imagination serves as the vehicle by which the poet traverses this space, anxiety is the factor which propels him towards self-manifestation, with the sixfold trope to illustrate the birthpangs of this phantom self-delivery onto a world of worry and 
struggle. Although Bloom seeks to undermine the entity of the Author by asserting that 'poets are inter-poets ${ }^{33}$, the entire scene nevertheless remains intrinsic to the psychology of the individual poet's mind, and the unity of the subject is never seriously impaired: the ephebe may be decentered, fixed in a dialectical pattern alternating between evasive and restorative swerves, 'presence' may echo other 'presences'; origins may be a trope and meaning "radically indeterminate» ${ }^{44}$, but the desire for originality and autonomy still remains the propelling force in Bloom's theory of text-production. So, as Lentricchia argues, "Bloom's exclusive concentration on the titanic willfulness of strong poets has succeeded in reinstating, against every theoretical point he has made, the principle of the author-if not in splendid isolation, then in splendid isolated dialogue with his strong ancestors $»^{45}$. The (poetic) self remains intact, authority, despite claims to the contrary, is not subordinated to tradition, the priority of Subject over object consistently enforced: Bloom's ephebe emerges finally equipped with a 'strong' voice that resounds above the deafening chorous of the canon: a marvellous fiction or $\mathrm{lie}^{46}$, and a tale of supreme individualism.

This brings us back to the declaration that first prompted my interest in Bloom's 'misreadings': »The Lurianic story of creation now seems to me the best paradigm available for a study of the way poets war against one another in the strife of Eternity that is poetic influence» ${ }^{47}$. It is striking from a literary point of view: the proposition that such esoteric material from the 'other', the Jewish, tradition should provide a model for 'our' literary canon was, in several corners of the academic world considered highly controversial, certainly in the mid 1970s when Bloom's ideas first appeared in print. From Jewish perspectives, however, it is not merely an astonishing claim, it is a travesty of the values embodied by Lurianic thought and in the rabbinic tradition at large, in so far as it peddles a view of kabbalistic authorship as inflected by competition. While stressing the necessity of interpretation, rabbis do not produce innovation on the basis of 'strife' and 'war'. On the contrary, exegesis is essentially a collaborative project which encompasses, even encourages deviation: disagreement and contradiction are written into standard methods of theological discourse, difference is seen as part of the same, a means to further understanding. Bloom's 'translation' of Lurianic and Cordoverovian theories of emanation into a drama 
of rivalry and radical individualism is thus a direct violation of the principles and values vested in Judaic intellectual culture. And Bloom founds his agonistic theory on precisely this misconception: the kabbalists as heroic heretics waging war on 'normative' rabbinics:

Confronting, as they did, not only a closed Book, but a vast system of closed commentary, the Kabbalists refused Neo-Aristotelian philosophical reductiveness, refused normative Rabbinicism with its pious repetition, and took the Gnostic path of expansive inventiveness, though in an uneasy alliance with Jewish Neoplatonic rather than Jewish Gnostic conceptions of the Godhead ${ }^{48}$.

There are several errors in this passage ${ }^{49}$, but most importantly, the notion of deviation which Bloom identifies with heresy - kabbalists cannot be said to have 'refused normative Rabbinicism'50. As we know, they focussed on the theosophical trend already incorporated within the canon and devoted themselves to studies of Torah as a sequence of Divine names. As such they merely responded to the interpretative imperative enjoined on any learned rabbi with a view, in fact, to possibly "alter the very content of Mosaic revelation ${ }^{51}$ by innovation. Kabbalah therefore is but a mode of thought encompassed by the normative: the esoteric tradition an integral part of the exoteric.

Where speculative kabbalah distinguishes itself from 'normative' Rabbinics is primarily in its linguistic approach to Creation and Scripture. Scholem emphasizes that

[a]ll creation - and this is an important principle of most Kabbalists- is, from the point of view of God, nothing but an expression of His hidden self that begins and ends by giving itself a name, the holy name of God, the perpetual act of creation. And all that lives is an expression of God's language... ${ }^{52}$.

Language is perceived as the origin of 'all creation' and any writing, by implication, will be merely a repetition of that which precedes it. The exegete therefore perceives himself as a scribe, a copyist; his work is considered indistinguishable from the textual tradition that fostered it, and so innovative ideas are unlikely to be ascribed to a particular commentator ${ }^{53}$.

Anonymity is inscribed in the rabbinic canon at large, but the kabbalists in particular seem to have carried it to an extreme, for, according to Scholem, they "glory in objective description and are deeply 
averse to letting their own personalities intrude into the picture...as though they were hampered by a sense of shame» and he continues, »our sources leave us completely in the dark as regards the personalities of many Kabbalists, including writers whose influence was very great and whose teachings it would be worth while to study in the light of biographical material, were any available» ${ }^{54}$.

Thus, given these paramount theological principles of interpretation and pseudoepigraphy, Bloom's view of Jewish exegesis, kabbalistic or otherwise, as 'rebellious' and 'heretical'55 emerges as a travesty. His attempt to ascribe a radical, competitive individualism to what is essentially a body of collective authorship reflects a serious misconception of the nature of rabbinic exegesis and a scant, ill-informed reading of Scholem. Diverse as the many 'esoteric' movements within Judaism have been, Scholem specifically emphasizes two features by which they have consistently concorded: the suppression of biographical and autobiographical material and the linguistic approach to all creation. Bloomian theory and practice diverge decisively on both points: his belated poet, struggling to clear a space for himself, could hardly differ more from kabbalists »deeply averse to letting their own personalities intrude into the picture ${ }^{56}$. It may be, as Susan Handelman argues, that Bloom and his 'heretic hermeneutics' set out to 'slay Moses'57, but the kabbalists will always concern themselves less with Moses than with the broken Tables he brought down from Mount Sinai.

\section{[3]}

Bloom has a way of making impressively forceful assertions which on reiteration appear to acquire the status of fact. As we have seen, his premises are often unsubstantiated and contradictory. This is most specifically the case in his presentation of rabbinic thought. In other words, Bloom's formal treatment of Judaic sources complies neither with elementary scholarly standards nor with rabbinic methods. His practice seems entirely unconstrained by standards external to itself: involving severe violations of linguistic rules and conceptual errors; appropriation and omission; series of misrepresentations, distortions, misapplications; and a complete disregard for distinctions between first and second-order representations. 
And beyond this catalogue of elementary errors, there is the problem with which I first began, that of the logical structure of Bloomian theory: in order to motivate his agonistics, Bloom self-declaredly misreads, but in effect misrepresents, a source itself held to promote misreading. But then there is no rational exit from this simultaneously self-confirming and self-defeating circle. One could scarcely ask for a more dramatic example of Bloom's idiosyncratically individualist way with the ideas of misprision, influence and agon. Where does such idiosyncracy leave us in relation to the more standard forms of scholarly evaluation? If we take the self-confirming view of Bloomian theory, then these principles simply go out the window, but at the cost of producing a travesty of the rabbinic tradition-the very source from which the theory claims its origins. His radically individualist conception of the poetic and critical agon, with its central stress on competitive, aggressive and even murderous relations between rivalrous subjects is, quite simply, profoundly unfaithful to and incompatible with the theological principles of pseudoepigraphy and interpretation as a collaborative effort, of fidelity to sources and other related values that inform the Judaic tradition. The subordination of the latter to the imperatives of the former produces what here I identify as major and serious distortions of kabbalistic thought and the tradition in which it is embedded. The effective outcome is a spectacular reversal of intellectual and historical priorities: recast in the mould of Bloom's heroic heresy, the Judaic tradition emerges as something miraculously constituted according to distinctively Bloomian specifications, a case, finally, not so much of the agonistic model originating in rabbinic thought as of the Judaic tradition re-written as itself Bloomian!

\section{Notes}

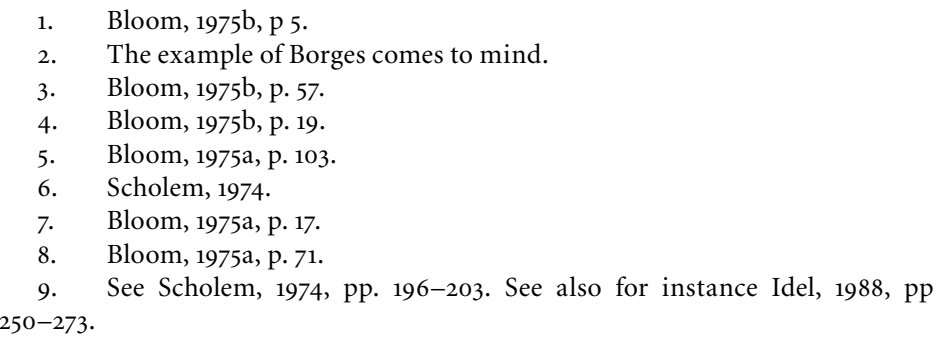


10. Scholem, 1972, p. 194.

11. Bloom, 1975a, p. 87.

12. Scholem, 1946; 1961, p. 249.

13. The Tetragrammaton, Yud, Heh, Vav, Heh.

14. According to Isaac the Blind as 'white fire upon black'. See Scholem, 1962; 1990, pp. 287-289.

15. Bloom, 1975a, p. 37 .

16. Bloom,1975b, pp. 96-97.

17. Bloom, 1975b, p. 97.

18. see Bloom, 1973, pp. 14-16, 10.

19. Cordovero, 1592.

20. The Influence of Gnosticism and Kabbalah in the Writings of Harold Bloom (unpublished prize essay, 1991), pp. 49-54.

21. Bloom, 1975a, p. 71.

22. Scholem, 1974, p. 114 .

23. My translation, Cordovero, Pardes Rimmonim, p. 63; see entire section five of the manuscript. Keter meaning 'crown' refers here to the first configuration in the s'firotic structure.

24. This erroneous sequential structure is directly transported into the 'Map of Misprision'.

25. Bloom, 1975a, pp. 66, 37.

26. Bloom, 1975a, p. 66.

27. Bloom, 1975a, pp. 36, 37.

28. Bloom, 1975a, p. 65.

29. Bloom, 1975 b, p. 95.

30. Bloom, 1975b, p. 95.

31. previous by virtue of being published earlier the same year, but that of course is no accurate guideline to the order in which the two volumes were written.

32. lidrosh is the infinitive form of the root darash, "to seek, enquire, ask; demand». Earlier in the same chapter, however, the forms are correctly matched, (see Map of Misreading, p. 42.)

33. Bloom, 1975b,b, pp. 54 .

34. Bloom, 1975a, p. 84.

35. Popular versions hold that God held his breath in order to produce a vacuum in which the universe took form.Umberto Eco, for instance, adopts this idea in Foucault's Pendulum, 1988.

36. Bloom, 1975a, p. 25.

37. both alef-yud-nun.

38. ayin-yud-nun.

39. Bloom, 1975a, p. 14; see also 1975b, pp. 44, 4.

40. F. Lentricchia refers to Kabbalah and Criticism as such in After the New Criticism, 1980, p. 343 .

41. Bloom, 1973, p. 10.

42. Bloom, 1973, p. 65.

43. Bloom, 1975a, p. 114 .

44. See Bloom, 1975b, p. 69.

45. Lentricchia, 1980 , p. 343

46. See Bloom, 1975b, p. 10.

47. Bloom, 1975b, p. 5.

48. Bloom, 1975a, p. 72. 
49. One is the perception of the Jewish canon as closed: where the 'Book' in its very capacity of being Revelation is inevitably 'closed', the various 'systems of commentary' were by no means closed when the major Kabbalistic schools emerged in the thirteenth century. Another is his disregard for historical chronology: Bloom does not distinguish between the early traditions of esoteric lore and medieval Kabbalah: the Kabbalists to whom he refers here were medieval theosophists thus succeeding the ancient throne mysticism which Scholem pairs with Gnosticism by a millenium or more. (See for instance Scholem, 1946; 1961, p. 40).

50. The appended 'ism here is not attested in the relevant literature.

51. J. Neusner, 1987, p. 74.

52. Scholem, 1946; 1961, p. 17.

53. Illustrative of this convention is an anonymous Rabbi's lament: „Our egos are not our own, our dreams and our thoughts are not our own, our will is not the one implanted in us; everything we were taught long ago, everything has been handed down to us» (cited by G. Hartman, "Imagination» in Contemporary Jewish Religious Thought, 1987, p. 461).

54. Scholem, 1946; 1961, pp.15-16.

55. See for instance Bloom, 1975a, p. 53; and 1973, p.29

56. Scholem, 1946; 1961, p. 16.

57. See Handelman, 1982.

\section{Bibliography}

Bloom, Harold, The Anxiety of Influence. A Theory of Poetry, Oxford: Oxford Univ. Press, 1973

-. Kabbalah and Criticism, New York: Seabury Press, 1975 a

-. A Map of Misreading, Oxford, Oxford Univ. Press, 1975b

Cordovero, Moshe, Pardes Rimmonim, Cracow, 1592

Eco, Umberto, Foucault's Pendulum, trans. W. Weaver, New York: Ballantine, 1988

Handelman, Susan, The Slayers of Moses. The Emergence of Rabbinic Interpretation in Modern Literary Theory, Albany: SUNY, 1982

Hartman, Geoffrey H., »Imagination» in Contemporary Jewish Religious Thought, ed.s A. Cohen and P. Mendes-Flohr, London: Macmillan, 1987

Idel, Moshe, Kabbalah. New Perspectives, New Haven: Yale Univ. Press, 1988

Lentricchia, Frank, After the New Criticism, London: Athlone Press, 1980

Neusner, Jacob, Judaism: A People and Its History, New York: Macmillan, 1987

Scholem, Gershom, Major Trends in Jewish Mysticism, New York: Schocken, 1946; 1961

-. Origins of the Kabbalah trans. A. Arkush, Princeton: Princeton Univ. Press, $1962 ; 1990$

-. »The Name of God and the Linguistic Theory of the Kabbala II,» Diogenes 80, 1972

-. Kabbalah, Jerusalem: Keter, 1974 
